\title{
WYBÓR ORZECZNICTWA
}

\section{Wyrok Trybunału Konstytucyjnego z dnia 8 grudnia 2009 r. SK 34/08, OTK Zbiór A 2009 nr 11 poz. 165}

Art. 5 ustawy z dnia 17 czerwca 2004 r. o zmianie ustawy - Kodeks cywilny oraz niektórych innych ustaw (Dz.U. Nr 162, poz. 1692) w zakresie, w jakim wyłącza skargę o stwierdzenie niezgodności z prawem orzeczenia sądu wyrządzającego szkodę, które stało się prawomocne po dniu wejścia w życie Konstytucji RP, jest niezgodny z art. 77 ust. 2 w związku z art. 45 ust. 1 Konstytucji Rzeczypospolitej Polskiej.

Ponadto postanawia na podstawie art. 39 ust. 1 pkt 1 ustawy z dnia 1 sierpnia 1997 r. o Trybunale Konstytucyjnym (Dz.U. Nr 102, poz. 643, z 2000 r. Nr 48, poz. 552 i Nr 53, poz. 638, z 2001 r. Nr 98, poz. 1070, z 2005 r. Nr 169, poz. 1417 oraz z 2009 r. Nr 56, poz. 459) umorzyć postępowanie w pozostałym zakresie ze względu na niedopuszczalność wydania wyroku.

Glosa częściowo krytyczna: P. Kociubiński

Skarga powstała na tle następującego stanu faktycznego:

„Skarżąca zobowiązała się oddać Małgorzacie M. jako najemcy oznaczony lokal mieszkalny na czas określony, a Małgorzata M. zobowiązała się płacić czynsz. Przed upływem oznaczonego w umowie terminu zakończenia najmu, Małgorzata M. wydała skarżącej lokal, zwróciła klucze oraz wezwała do zwrotu wpłaconej kaucji. W związku z odmową skarżącej, Małgorzata M. wniosła o zasądzenie kwoty stanowiącej równowartość wniesionej kaucji wraz z odsetkami.

Sąd Rejonowy dla Wrocławia-Śródmieścia, Wydział I Cywilny, w wyroku z 1 października 2002 r. (sygn. akt I C upr. 78/02) wydanym w postępowaniu uproszczonym częściowo uwzględnił powództwo. Od wyroku skarżąca wniosła apelację, która została oddalona wyrokiem Sądu Okręgowego we Wrocławiu z 28 lutego 2003 r. (sygn. akt II Ca 114/03).

Skarżąca wniosła skargę o stwierdzenie niezgodności z prawem prawomocnego wyroku Sądu Okręgowego z 28 lutego 2003 r. (sygn. akt II Ca 114/03) w całości oraz wyroku Sądu Rejonowego z 1 października 2002 r. (sygn. akt I C upr. 78/02) w oznaczonym zakresie. 
Postanowieniem z 13 lutego 2007 r. (sygn. akt V CNP 177/06) Sąd Najwyższy odrzucił skargę. Przytaczając stanowisko wyrażone w uchwale siedmiu sędziów Sądu Najwyższego z 26 października 2005 r. (sygn. akt III BZP 1/05, OSNC nr 5/2006, poz. 78), Sąd Najwyższy rozstrzygnął, że skarga o stwierdzenie niezgodności z prawem prawomocnego orzeczenia sądowego przysługuje od orzeczeń, które stały się prawomocne od 1 września 2004 r. Kwestionowany przez skarżącą wyrok Sądu Okręgowego stał się prawomocny przed 1 września 2004 r., dlatego Sąd Najwyższy uznał go za niezaskarżalny, a skargę za niedopuszczalną".

\section{Z uzasadnienia Trybunału Konstytucyjnego:}

„(...) Trybunał Konstytucyjny stwierdza, że zaskarżony przepis w zakresie oznaczonym w sentencji zamyka drogę sądową dochodzenia naruszonych praw oraz uniemożliwia rozpoznanie sprawy o odszkodowanie za niezgodne z prawem działanie władzy publicznej polegające na wydaniu orzeczenia sądu cywilnego.

Mając na uwadze, że od 17 października 1997 r. obowiązuje konstytucyjna zasada kompensacji szkód wyrządzonych bezprawnym działaniem władzy publicznej, a derogacja art. $418 \mathrm{kc}$. nie doprowadziła do powstania luki prawnej w zakresie odpowiedzialności odszkodowawczej za bezprawie judykacyjne, należy uznać, że od momentu wejścia w życie Konstytucji istnieje materialna podstawa roszczeń z tytułu szkody wyrządzonej niezgodnym z prawem orzeczeniem sądu. W konsekwencji, przed wprowadzeniem szczegółowej regulacji wynikającej z art. $417^{1} \S$ $2 \mathrm{kc}$. poszkodowany mógł poszukiwać ochrony prawnej na podstawie art. $417 \mathrm{kc}$. w związku z art. 77 ust. 1 Konstytucji.

Zważywszy jednak, że konstytucyjne prawo do wynagrodzenia szkody zakłada stworzenie odpowiedniej procedury dochodzenia tego prawa, a w zakresie odpowiedzialności za szkodę wyrządzoną bezprawiem judykacyjnym procedura ta powinna przybrać postać sądowego rozstrzygnięcia o niezgodności z prawem orzeczenia w postępowaniu sądowym (por. cytowany wyrok w sprawie o sygn. SK 77/06), możliwość dochodzenia roszczeń z tytułu wyrządzonej szkody powiązana została z możliwością realizacji roszczenia o stwierdzenie niezgodności z prawem prawomocnego orzeczenia.

$\mathrm{Z}$ uwagi na art. 5 ustawy zmieniającej kc. poszkodowani legitymujący się orzeczeniem, które uprawomocniło się przed 1 września 2004 r., nie mogli skutecznie skorzystać z drogi sądowej dochodzenia naruszonych praw. W obowiązującym stanie prawnym uzyskanie stosownego orzeczenia prejudycjalnego w omawianym zakresie odpowiedzialności władzy publicznej jest warunkiem prawnym realizacji prawa do odszkodowania.

$(\ldots)$ 
Zważywszy, że od 17 października 1997 r. do 1 września 2004 r. brak było uniwersalnego i powszechnego instrumentu procesowego umożliwiającego stwierdzenie niezgodności z prawem prawomocnych orzeczeń, a wprowadzona mocą ustawy zmieniającej k.p.c. skarga stanowi autonomiczny, uniwersalny i konieczny instrument stwierdzania przesłanki niezgodności z prawem orzeczenia sądu cywilnego, należy uznać, że zamknięcie drogi sądowej - przez wyłączenie możliwości wniesienia skargi o stwierdzenie niezgodności z prawem orzeczenia sądu cywilnego oznacza zarazem (w szczególności) pozbawienie poszkodowanych prawa do prawidłowo ukształtowanej procedury sądowej oraz prawa do uzyskania wiążącego rozstrzygnięcia sądu odszkodowawczego. Od 17 października 1997 r. do 1 września 2004 r. nie było możliwe spełnienie warunku prawnego, jakim jest uzyskanie prejudykatu stwierdzającego niezgodność z prawem orzeczenia sądu cywilnego. Poszkodowani nie mogli efektywnie korzystać z przysługującego im prawa do sądu w zakresie postępowania odszkodowawczego.

Konkludując, Trybunał Konstytucyjny stwierdza, że art. 5 ustawy zmieniającej kc., w zakresie oznaczonym w sentencji, jest niezgodny z art. 77 ust. 2 w związku z art. 45 ust. 1 Konstytucji."

\section{Orzeczenie Trybunału Konstytucyjnego z dnia 28 maja 1997 r. K 26/96, OTK 1997 nr 2, poz. 19}

1. Art. 1 pkt 2 ustawy z dnia 30 sierpnia 1996 r. o zmianie ustawy o planowaniu rodziny, ochronie płodu ludzkiego i warunkach dopuszczalności przerywania ciąży oraz zmianie niektórych innych ustaw (Dz.U. Nr 139, poz. 646), w zakresie w jakim uzależnia ochronę życia w fazie prenatalnej od decyzji ustawodawcy zwykłego, jest niezgodny $\mathrm{z}$ art. 1 oraz art. 79 ust. 1 przepisów konstytucyjnych pozostawionych w mocy na podstawie art. 77 Ustawy Konstytucyjnej z dnia 17 października 1992 r. o wzajemnych stosunkach między władzą ustawodawczą i wykonawczą Rzeczypospolitej Polskiej oraz o samorządzie terytorialnym (Dz.U. Nr 84 poz. 426; zm.: z 1995 r. Nr 38 poz. 148, Nr 150, poz. 729; z 1996 r. Nr 106, poz. 488) przez to, że

narusza konstytucyjne gwarancje ochrony życia ludzkiego w każdej fazie jego rozwoju.

\section{$(\ldots)$}

glosa krytyczna: J. Woleński Glosa do orzeczenia TK z dnia 28 maja 1997 r., K 26/96.

glosa częściowo krytyczna: W. Lang Glosa do orzeczenia TK z dnia 28 maja 1997 r., K 26/96. 
„Grupa Senatorów Rzeczpospolitej Polskiej we wniosku z 11 grudnia 1996 r. wniosła o zbadanie zgodności art. 1 ust 2, ust. 4 pkt b i c, ust. $5 \mathrm{w}$ zakresie dotyczącym art. 4a ust. 1, art. 2 ust. 1 i 2 oraz art. 3 ust. 1, 2 i 4 ustawy z dnia 30 sierpnia 1996 r. o zmianie ustawy o planowaniu rodziny, ochronie płodu ludzkiego i warunkach dopuszczalności przerywania ciąży oraz zmianie niektórych innych ustaw (Dz.U. Nr 139, poz. 646) z art. 1, art. 67 ust. 1 i 2 oraz art. 79 ust. 1 przepisów konstytucyjnych pozostawionych w mocy na podstawie art. 77 Ustawy Konstytucyjnej z dnia 17 października 1992 r. o wzajemnych stosunkach między władzą ustawodawczą i wykonawczą Rzeczypospolitej Polskiej oraz o samorządzie terytorialnym (Dz.U. Nr 84 poz. 426; zm.: z 1995 r. Nr 38 poz. 148, Nr 150, poz. 729; z 1996 r. Nr 106, poz. 488)."

\section{Z uzasadnienia Trybunału Konstytucyjnego:}

„Stwierdzenie, że życie człowieka w każdej fazie jego rozwoju stanowi wartość konstytucyjną podlegającą ochronie nie oznacza, że intensywność tej ochrony w każdej fazie życia i w każdych okolicznościach ma być taka sama. Intensywność ochrony prawnej i jej rodzaj nie jest prostą konsekwencją wartości chronionego dobra. Na intensywność i rodzaj ochrony prawnej, obok wartości chronionego dobra, wpływa cały szereg czynników różnorodnej natury, które musi brać pod uwagę ustawodawca zwykły decydując się na wybór rodzaju ochrony prawnej i jej intensywności. Ochrona ta jednak powinna być zawsze dostateczna z punktu widzenia chronionego dobra.

\section{( ...)}

Stanowisko, w myśl którego zdrowie ludzkie powinno podlegać ochronie prawnej także w fazie prenatalnej, znajduje bezpośrednie potwierdzenie w Konwencji o Prawach Dziecka. Art. 24 ust. 1 Konwencji stwierdza, iż Państwa-Strony uznają prawo dziecka do korzystania z możliwie najlepszego stanu zdrowia (...). W ustępie drugim tego artykułu stwierdzono natomiast, iż Państwa-Strony będą starały się zapewnić pełne urzeczywistnienie tego prawa, a w szczególności będą podejmowały właściwe środki w celu: (...) d) zapewnienia matkom właściwej opieki prenatalnej i postnatalnej. Bez względu więc na brzmienie akapitu 10 preambuły do Konwencji, w świetle którego pojęcie dziecka użyte w Konwencji, powinno obejmować także dziecko przed urodzeniem, art. 24 zawiera bezpośrednią wskazówkę, iż prawo do korzystania z możliwie najlepszego stanu zdrowia obejmuje również dziecko poczęte. Tylko w ten sposób można wytłumaczyć wynikające z ust. 2 zobowiązanie do zapewnienia matkom opieki prenatalnej. Zobowiązanie to nie zostało bowiem wprowadzone ze względu na interes samej kobiety ciężarnej ale, jak wyraźnie stanowi to art. 24 ust. 2 in principio, aby zapewnić pełne urzeczywistnienie tego (tj. określonego w ust. 1) prawa. Wyraźnie więc chodzi tutaj o gwarancje dla dziecka poczętego do korzystania z możliwie najlepszego stanu zdrowia. 


\section{(...)}

Jeżeli bowiem życie człowieka, w tym życie dziecka poczętego, stanowi wartość konstytucyjną, to ustawa zwykła nie może prowadzić do swoistej cenzury i zawieszenia obowiązywania norm konstytucyjnych. Zakaz naruszania życia ludzkiego, w tym życia dziecka poczętego wynika z norm o charakterze konstytucyjnym. W takiej sytuacji ustawodawca zwykły nie może więc być uprawniony do decydowania o warunkach obowiązywania takiego zakazu, czyniąc tym samym normy konstytucyjne normami o charakterze warunkowym. Nie może w szczególności uzależniać go od regulacji zawartych w ustawach zwykłych. Stąd też sprzeczne z normami konstytucyjnymi jest stanowienie przez ustawodawcę zwykłego wszelkich takich regulacji, które prowadziłoby do jedynie warunkowego obowiązywania gwarancji konstytucyjnych.

\section{(...)}

Należy stanąć na stanowisku, iż konstytucja może być i jest bezpośrednim źródłem zakazów i nakazów obowiązujących w systemie prawa, a odnoszących się do określonych wartości konstytucyjnych. Już z samej więc konstytucji wynika zakaz naruszania wolności słowa, wolności zgromadzeń, naruszania nietykalności osobistej, czy tajemnicy korespondencji. Jednocześnie jednak posługując się samą tylko konstytucją, dla ostatecznego ustalenia bezprawności zachowania naruszającego czy ograniczającego określoną wartość konstytucyjną, niezbędne byłoby ustalenie, czy zachowanie to znajduje dostateczne usprawiedliwienie w związku z realizacją innej wartości konstytucyjnej. W szczególności np. naruszenie życia napastnika może być uzasadnione koniecznością ochrony życia ofiary.

Mimo więc tej bezpośredniej mocy regulacyjnej konstytucji ustawodawca zwykły nie jest zwolniony z obowiązku stanowienia norm merytorycznych odnoszących się do ochrony wartości konstytucyjnych, w szczególności jednak powinien on rozstrzygać w sposób generalny kolizje, jakie mogą powstawać w związku z praktyczną realizacją wartości konstytucyjnych. Ustawodawca powinien nadto określić sposoby egzekwowania norm merytorycznych - konstruując zarówno konsekwencje prawne ich nieprzestrzegania jak i procedury egzekwowania.

W tym ostatnim zakresie ustawodawca ma dużą swobodę realizowania określonej polityki zapewniającej skuteczność stanowionych norm merytorycznych. Swoboda ta nie może jednak przekraczać pewnych granic. W szczególności ustawodawca nie może całkowicie zrezygnować z ochrony określonych dóbr prawnych lecz ma obowiązek zapewnienia im „,dostatecznej ochrony”.

\section{(...)}

Z istoty uznania życia ludzkiego za wartość konstytucyjną wynika konieczne ograniczenie praw kobiety ciężarnej. Rozwijające się życie nie tylko korzysta z dóbr 
matki w znaczeniu biologicznym, ale także ze względów czysto faktycznych może ograniczać matkę w możliwościach korzystania z przysługujących jej praw i wolności. Także w sferze prawnej, korelatem rozwijającego się życia dziecka jest zespół obowiązków złożonych zarówno na matkę dziecka jak i jego ojca, gwałtownie wzrastający z momentem narodzin. W sposób konieczny poczęcie dziecka i przyznanie ochrony prawnej życiu w fazie prenatalnej łączy się z powstaniem obowiązków matki i ojca dziecka. Ta zmiana sytuacji prawnej nie stanowi usprawiedliwienia dla pozbawienia życia dziecka poczętego. Przepisy konstytucyjne, przewidując ochronę prawną macierzyństwa oraz rodziny, zakładają, że obowiązki rodzicielskie nie mogą wpływać na zakres ochrony życia dziecka poczętego.

\section{( ...)}

Zdolność prawna, o której mowa w art. 8 jest warunkiem nabywania praw w zakresie prawa cywilnego zarówno o charakterze majątkowym jak i niemajątkowym.

Oczywiście skreślenie art. $8 \S 2$ nie oznacza, iż w ogóle, w całym zakresie prawa cywilnego dziecko poczęte utraciło zdolność bycia podmiotem przewidzianych w tej dyscyplinie praw. Art. $927 \S 2$ kc przesądza o tym, iż dziecko poczęte może być podmiotem praw wynikających ze spadku. Zgodnie z art. 182 kodeksu rodzinnego i opiekuńczego dla dziecka poczętego, lecz jeszcze nie urodzonego, można ustanowić kuratora. Wynika stąd jednoznacznie, iż przepis szczególny może, w zakresie regulowanych w nim stosunków prawnych, kreować zdolność prawną dziecka poczętego.

Samo skreślenie generalnej klauzuli zawartej w art. $8 \S 2$ kc nie musi prowadzić automatycznie do braku jakiejkolwiek zdolności prawnej dzieci poczętych. Brak, przed 1993 r., tej klauzuli nie przeszkadzał sądom w konstruowaniu takiej zdolności w zakresie niektórych praw przewidzianych w kodeksie cywilnym, na zasadzie interpertacji poszczególnych przepisów prawa cywilnego. W doktrynie wyrażany jest pogląd, że wprowadzenie do kodeksu cywilnego art. 8 § 2 nie stanowiło ,istotnej nowości w stosunku do tego, co judykatura i doktryna przyjmowały na tle dotychczasowych przepisów kodeksu cywilnego" (zob. A. Mączyński, K. Zawada, Kwartalnik Prawa Prywatnego, z. 3/1995, s. 418). Nie ma podstaw do negowania dalszej aktualności tego dorobku po uchyleniu art. $8 \S 2 \mathrm{kc}$. Niektóre roszczenia (np. w tzw. sprawach kombatanckich, na które powołuje się wnioskodawca) mogą być oparte, jak słusznie zwrócił na to uwagę w czasie rozprawy przedstawiciel Prokuratora Generalnego, $\mathrm{o}$ art. $446^{1} \mathrm{kc}$.

Decyzja ustawodawcy o skreśleniu generalnej klauzuli przyznającej zdolność prawną jest więc w istocie uzasadniona tym, iż ze względu na status psychofizyczny płodu jego zdolności do „bycia” podmiotem praw określonych w prawie cywilnym jest dość ograniczona. Zdolność prawna, o której mówią przepisy kodeksu cywilnego, ma charakter czysto funkcjonalny i odnosi się wyłącznie do insty- 
tucji prawa cywilnego. W szczególności nie można utożsamiać zdolności prawnej określonej $\mathrm{w}$ art. $8 \mathrm{kc}$. $\mathrm{z}$ podmiotowością prawną $\mathrm{w}$ całym systemie prawa. Podmiotowość prawna przynależna jest każdemu człowiekowi. Zdolność prawna w zakresie prawa cywilnego może być natomiast uzależniona od etapu rozwoju życia ludzkiego. W żaden więc sposób, nie można odczytywać tej decyzji w kontekście całkowitego pozbawienia nasciturusa zdolności prawnej w całym zakresie prawa cywilnego, czy systemu prawa. Rezygnacja z generalnej klauzuli przyznającej zdolność prawną w zakresie prawa cywilnego w żaden sposób nie rzutuje także na objęcie ochroną prawną tak istotnych dóbr prawnych, jak życie czy zdrowie nasciturusa a w szczególności jego godność (por. pkt 10 rekomendacji 1046 Rady Europy nakazujący traktowanie embrionu lub płodu ludzkiego we wszelkich okolicznościach z szacunkiem należnym godności ludzkiej). Jak już wcześniej wspomniano podstawy tej ochrony zakorzenione są w przepisach o charakterze konstytucyjnym.

\section{Wyrok Sądu Najwyższego z dnia 18 lutego 2009 r. III KK 349/08, LEX nr 491550}

Sądy obu instancji, zgodnie z regułą intertemporalną wyrażoną w art. 4 § kk. z 1997 r. stanowiącą, iż należy stosować ustawę obowiązującą w czasie orzekania (nową), chyba że jej zastosowanie prowadzi do pogorszenia sytuacji sprawcy, powinny były, przed dokonaniem oceny prawnej czynów, rozważyć w pierwszej kolejności, które unormowania in concreto są względniejsze dla oskarżonej w odniesieniu do każdego z zarzucanych jej czynów. Przenosząc powyższe rozważania na grunt przedmiotowej sprawy, sądy orzekające zobowiązane były wskazać przyczyny i powody, dla których 10 czynów popełnionych przez oskarżoną E. S.-G. w czasie obowiązywania stanu prawnego poprzedzającego wejście w życie Kodeksu karnego z 1997 r. zostało ocenionych na płaszczyźnie stanu prawnego obowiązującego w czasie orzekania. (...) Porównanie katalogu kar dodatkowych zawartego w art. 38 kk. z 1969 r. z zawartą w Kodeksie karnym z 1997 r. instytucją obligatoryjnego naprawienia szkody wynikającą z art. $46 \S 1$ kk., której poprzedni Kodeks karny nie przewidywał nawet $\mathrm{w}$ formie fakultatywnej, wynika, że względniejszą ustawą dla oskarżonej, która powinna stanowić podstawę prawną orzekania co do czynów popełnionych przed 1 września 1998 r., jest Kodeks karny z 1969 r. Surowsze limity kary odbytej, przewidziane w Kodeksie karnym z 1969 r. do udzielenia warunkowego przedterminowego zwolnienia, w porównaniu do zasad karnych przewidzianych w Kodeksie karnym z 1997 r. w tym zakresie nie mają wpływu na ocenę względności ustaw w świetle art. 4 § $1 \mathrm{kk}$. Od dnia wejścia w życie Kodeksu karnego z 1997 r. warunkowe zwolnienie z odbycia reszty kary udzielane jest według zasad przewidzianych w tym Kodeksie bez względu na uprawnienia wynikające $\mathrm{z}$ regulacji poprzedniego Kodeksu karnego. 


\section{Uchwała Sądu Najwyższego z dnia 24 lutego 2009 r. III CZP 2/09, LEX nr 492286}

1. W stanie prawnym wprowadzonym przez art. $442^{1}$ można zasadnie twierdzić, że wyeliminowane zostało niebezpieczeństwo upływu terminu przedawnienia roszczenia o naprawienie szkody na osobie wcześniej niż szkoda ta się ujawniła.

2. Wprowadzenie uregulowania, że bieg terminu przedawnienia roszczenia o naprawienie szkody na osobie rozpoczyna się z chwilą dowiedzenia się przez poszkodowanego o szkodzie i osobie zobowiązanej do jej naprawienia (bo tak należy odczytać $\S 3$ art. $442^{1} \mathrm{kc}$.) oznacza, że nie został w żaden sposób ograniczony czas, w jakim może ujawnić się szkoda na osobie prowadząc do powstania (zaktualizowania się) odpowiedzialności pozwanego za skutki danego zdarzenia. Drugi, czy kolejny proces odszkodowawczy może więc toczyć się nawet po dziesiątkach lat od wystąpienia zdarzenia wyrządzającego szkodę. Trudności dowodowe z biegiem lat narastają, a przesądzenie w sentencji wyroku zasądzającego świadczenie odszkodowawcze o odpowiedzialności pozwanego za szkody mogące powstać w przyszłości, zwalnia powoda (poszkodowanego) z obowiązku udowodnienia istnienia wszystkich przesłanek odpowiedzialności podmiotu, na którym taka odpowiedzialność już ciąży.

\section{Wyrok Sądu Najwyższego z dnia 12 sierpnia 2009 r. IV CSK 146/09, Wspólnota 2009 nr 36 s. 29}

Prawem właściwym dla spadku są przepisy obowiązujące w chwili śmierci spadkodawcy. Jeśli w tym czasie istniały ograniczenia związane z nabywaniem gospodarstwa rolnego poprzez spadkobranie, sąd, wydając postanowienie o nabyciu spadku, jest obowiązany je uwzględnić.

\section{Wyrok Sądu Najwyższego z dnia 9 października 2008 r. WA 40/08, OSNwSK 2008 nr 1, poz. 1994}

Przy rozważaniu problemu względności ustaw (w tym w kontekście ustania karalności czynu) nie należy poprzestawać wyłącznie na porównaniu ustawy nowej z ustawą obowiązującą $\mathrm{w}$ dacie popełnienia przestępstwa, lecz należy brać pod uwagę wszystkie zmiany stanu prawnego zaistniałe między datą popełnienia przestępstwa, a datą orzekania tak, by zgodnie z regułą opisaną w art. $4 \S 1 \mathrm{kk}$. doszło do oceny zachowania sprawcy przez pryzmat przepisów dlań najkorzystniejszych. 


\section{Wyrok Sądu Najwyższego z dnia 23 stycznia 2007 r. III PK 96/06, OSNP 2008 nr 5-6, poz. 61}

1. Odroczenie wejścia w życie orzeczenia Trybunału Konstytucyjnego (art. 190 ust. 3 Konstytucji RP) stwierdzającego sprzeczność przepisu ustawy z Konstytucją nie stanowi przeszkody do uznania przez sąd, że przepis ten był sprzeczny z Konstytucją od jego uchwalenia.

2. Sąd może odmówić stosowania art. $442 \S 1$ zdanie drugie kc. w odniesieniu do zdarzeń wyrządzających szkodę na osobie zaistniałych od dnia jego wejścia w życie. Roszczenia z tytułu tych szkód ulegają przedawnieniu z upływem lat trzech od dnia, w którym poszkodowany dowiedział się o szkodzie i osobie obowiązanej do jej naprawienia (art. $442 \S 1$ zdanie pierwsze kc.).

\section{Wyrok Sądu Najwyższego z dnia 25 maja 2007 r. I CSK 84/07, OSNC-ZD 2008 nr 2, poz. 35}

Przepisy międzyczasowe zawarte w ustawie z dnia 23 kwietnia 1964 r. - Przepisy wprowadzające kodeks cywilny (Dz.U. Nr 16, poz. 94 ze zm.) mają zastosowanie w drodze analogii do ustaw nowelizujących kodeks cywilny, chyba że stanowią one inaczej.

\section{Wyrok WSA w Białymstoku z dnia 27 października 2005 r. II SA/Bk 503/05, LEX nr 173719}

Po uchyleniu $\S 2$ art. $8 \mathrm{kc}$. generalnie możność warunkowego stania się podmiotem praw przez nasciturusa dopuszczalna jest jedynie wówczas, gdy wynika to wprost z przepisów szczególnych. Ustawa o świadczeniu pieniężnym przysługującym osobom deportowanym do pracy przymusowej oraz osadzonych w obozach pracy przez III Rzeszę i Związek Socjalistycznych Republik Radzieckich (Dz.U. z 1996 r. Nr 87, poz. 395 z późn. zm.) takiej szczególnej regulacji nie zawiera. Dlatego też okres represji nie może być liczony od dnia poczęcia.

\section{Wyrok Sądu Najwyższego z dnia 29 maja 1996 r. III ARN 96-95, OSNP 1996/24/366}

Pojęcie "osoba podlegająca represjom w hitlerowskich obozach koncentracyjnych" oznacza również dziecko poczęte, jeżeli urodziło się żywe (art. 4 ust. 1 pkt 1 lit. a ustawy z dnia 24 stycznia 1991 r. o kombatantach oraz niektórych osobach będących ofiarami represji wojennych i okresu powojennego, Dz.U. Nr 17, poz. 75 ze zm. w zw. z art. 8 \& 2 kc. i art. 1 ust. 1 ustawy z dnia 7 stycznia 1993 r. o planowaniu rodziny, ochronie płodu ludzkiego i warunkach dopuszczalności przerywania ciąży, Dz.U. Nr 17, poz. 78.). 


\section{Uchwała Sądu Najwyższego z dnia 29 grudnia 1995 r. III CZP 181/95, OSNC 1996 nr 4, poz. 50}

Dopuszczalne jest założenie księgi wieczystej dla nieruchomości stanowiącej budynek bądź piętro budynku, nabytej pod rządem nie obowiązującego obecnie kodeksu cywilnego Napoleona.

\section{Postanowienie Sądu Najwyższego z dnia 17 października 1969 r. II CR 512/69, LEX nr 6587}

1. Powszechny jest pogląd o deklaratywnym charakterze wyroków ustalających ojcostwo. Wyrok taki stwierdza tylko stan istniejący już od chwili poczęcia dziecka (art. $927 \S 2$ kc.).

2. Znaczenie prawne ma natomiast data 1.X.1950 r. dotycząca zniesienia ograniczeń prawnych tzw. dawniej dzieci pozamałżeńskich. Jeżeli bowiem ojciec takiego dziecka zmarł przed tą datą, dziecko takie po nim nie dziedziczy także wówczas, gdy ustalenie ojcostwa nastąpiło po tej dacie.

\section{Wyrok Sądu Najwyższego z dnia 2 czerwca 1967 r. III PRN 38/67, LEX nr 6167}

Wykładnia art. XLIX $\S 1$ przep. wprow. kc. prowadzi do wniosku, że nie stosuje się nowej ustawy przy ocenie skutków czynu niedozwolonego, który zdarzył się przed jej wejściem w życie. Na skutek wypadku powstał bowiem stosunek zobowiązaniowy, którego treść jest bezpośrednim następstwem omawianego zdarzenia prawnego.

Przepisy kodeksu zobowiązań miałyby więc zastosowanie nawet wówczas, gdyby wypadek nastąpił przed dniem 1.I.1965 r. a śmierć denata po dniu 31.XII.1964 r.

Słowa kluczowe: odpowiedzialność cywilna, małoletni, nadzór, wina

\section{Wyrok Sądu Najwyższego z dnia 2 lutego 2011 r. II CSK 392/10, OSNC-ZD 2011 nr 4, poz. 87}

1. Każdy ustalony fakt powinien nastąpić w oparciu o konkretnie powołane dowody, a następnie należało kompleksowo je omówić, wskazując zwłaszcza dlaczego odmiennym od ustaleń środkom dowodowym odmawia się wiarygodności.

2. Obowiązek przestrzegania niezbędnych wymagań w dziedzinie bezpieczeństwa młodzieży w szkole nie ogranicza się do wydania konkretnych nakazów, czy zakazów wynikających wprost z przepisów szczegółowych, lecz 
polega na stosowaniu - wynikających z zasad ogólnych - wszelkiego rodzaju środków ochrony przez nauczycieli wobec powierzonych ich pieczy uczniów. Zasady te powinny być honorowane w stosunkach szkolnych zarówno ze względu na bezpieczeństwo uczącej się młodzieży, jak i dla celów wychowawczych, polegających na wytworzeniu nawyku poszanowania własnego i cudzego bezpieczeństwa.

\section{Wyrok Sądu Najwyższego z dnia 24 września 2009 r. IV CSK 207/09, Biuletyn SN 2009 nr 11, s. 13}

I. Ustalenie, że przyczyną szkody było zachowanie małoletniego, który ukończył 13 lat, lecz winy mu przypisać nie można, nie wyłącza odpowiedzialności prowadzącego zakład na podstawie art. $435 \mathrm{kc}$.

II. W wyroku wstępnym sąd nie orzeka o przyczynieniu się poszkodowanego.

\section{Wyrok Sądu Najwyższego z dnia 8 lutego 1977 r. IV CR 8/77, LEX nr 7909}

Względy wychowawcze przemawiają za przyjęciem, że nadzór nad młodzieżą starszą nie może być ciągły, gdyż młodzieży takiej należy stwarzać warunki do znacznej samodzielności.

Za wadliwą i nie zapewniającą takiej młodzieży należytej opieki uznać trzeba taką organizację nadzoru, przy której w stałych, i z góry znanych i długich odcinkach czasu nie może on być wykonywany nawet sporadycznie.

\section{Wyrok Sądu Najwyższego z dnia 27 stycznia 1971 r. III CRN 448/70, LEX nr 6863}

Rodzice odpowiadają z tytułu nadzoru za szkodę wyrządzoną w sposób zawiniony przez małoletniego powyżej 13 lat, wtedy, gdy zostanie im udowodniona konkretna wina (art. $415 \mathrm{kc}$.) pozostająca w związku przyczynowym ze szkodą.

Nie można uznać za uzasadnione dopatrywania się winy pozwanych małżonków jedynie w tym, że prawie 17-letni ich syn był na zabawie poza godz. 24-tą w świetlicy gromadzkiej, znajdującej się w tej samej wsi, w której mieszkał.

\section{Uchwała Sądu Najwyższego z dnia 26 czerwea 1959 r. I CO 18/59, OSNCK $1960 \mathrm{nr} 3$, poz. 80}

Za szkodę wyrządzoną zawinionym czynem małoletniego odpowiadają również rodzice $\mathrm{z}$ tytułu braku nadzoru, jeśli zostanie udowodnione, że szkoda pozostaje w związku przyczynowym z określonym ich zaniedbaniem (art. 134 k.z.). 
Sowa kluczowe: zobowiązanie, wierzytelność, dług

Wyrok Sądu Najwyższego z dnia 12 marca 2010 r.

III CNP 27/09, Biuletyn SN 2010, nr 7, s. 9, OSNC-ZD 2010 nr 4, poz. 105

O bycie zobowiązania rozstrzyga istnienie, znajdującego wyraz w jego treści, godnego ochrony interesu wierzyciela; gdy tego interesu brak, zobowiązanie nie powstaje, a powstałe wygasa.

\section{Wyrok Sądu Najwyższego z dnia 8 sierpnia 2008 r. \\ V CSK 87/08, OSNC-ZD 2009 nr 2, poz. 57}

Przy wykonywaniu zobowiązań umownych mają znaczenie tylko takie zwyczaje, które zostały już ukształtowane w odniesieniu do pewnej kategorii stosunków obligacyjnych i są powszechnie znanym oraz aprobowanym sposobem postępowania.

Słowa kluczowe: własność nieruchomości, zasiedzenie,

\section{Postanowienie Sądu Najwyższego z dnia 7 października 2010 r. IV CSK 152/10, LEX nr 707912}

1. Zasiedzenie jest odstępstwem od zasady nienaruszalności prawa własności. Dlatego wszelkie wątpliwości powinny być tłumaczone na korzyść ochrony własności (innych praw majątkowych), bez względu na to, czy chodzi o własność (prawa majątkowe) osób fizycznych, jednostek samorządu terytorialnego, Skarbu Państwa, czy innych podmiotów. Nie ma przeto żadnych podstaw ani prawnych ani aksjologicznych ani teleologicznych aby oznaczonej grupie właścicieli ochronę tę ograniczać.

2. W złej wierze jest ten, kto wie albo wiedzieć powinien, że prawo własności przysługuje nie jemu, lecz innej osobie. Oznacza to, że ocenie podlega zasadność przeświadczenia nabywcy o przysługującym mu prawie przy uwzględnieniu wszystkich okoliczności towarzyszących.

\section{Wyrok Sądu Najwyższego z dnia 8 sierpnia 2008 r. \\ V CNP 24/08, LEX nr 465960}

Nikt poza Skarbem Państwa lub jednostkami samorządu terytorialnego nie powinien być właścicielem gruntów, które zajęte są pod drogi publiczne. Skarb Państwa nie może skutecznie przenieść prawa własności do działek zajętych pod drogi publiczne na osobę fizyczną.

Słowa kluczowe: prawo karne, zasady procesowe 


\section{Postanowienie Sądu Najwyższego z dnia 28 kwietnia 2009 r. II KK 96/09, LEX nr 507935}

Obraza art. 4 kpk. nie może w ogóle stanowić podstawy zarzutu kasacyjnego. Przepis ten formułuje procesową zasadę obiektywizmu, przestrzeganie, której gwarantowane jest szczegółowymi przepisami procedury karnej. Przyjęcie, że doszło do naruszenia tej zasady wymaga więc wykazania obrazy poszczególnych przepisów gwarantujących jej przestrzeganie.

\section{Wyrok Sądu Najwyższego z dnia 10 stycznia 2008 r. III KK 326/07, LEX nr 359599}

Generalne zasady procedowania w procesie karnym nakazują organom badać oraz uwzględnić wszystkie okoliczności przemawiające zarówno na korzyść, jak i na niekorzyść oskarżonego. Jest to wyraz postulatu procesowego, by ustalenia faktyczne odpowiadały prawdzie. W postępowaniu jest to osiągalne tylko wtedy, gdy przedmiotem zainteresowania jest cały zebrany w sprawie materiał dowodowy bez pominięcia istotnych jego części i gdy całokształt tego materiału - po prawidłowym ujawnieniu go w procesie - stanie się następnie przedmiotem rozważań sądu.

\section{Postanowienie Sądu Najwyższego z dnia 30 lipca 2008 r., II KK 93/08, LEX nr 448993}

1. Przepisy art. 4, $2 \S 2,2 \S 2$ pkt 1 kpk. w ogóle nie mogą być samodzielną podstawą kasacji, ponieważ formułują one tylko zasady procesowe, których wysoki poziom abstrakcji normatywnej powoduje, że bez powiązania ich z konkretnymi przepisami prawa procesowego, „ucieleśniającymi” te wskazania ogólne, wykluczone jest posługiwanie się nimi nie tylko w kasacji, ale w jakimkolwiek środku odwoławczym.

2. Brak podstaw do przyjęcia, że Sąd Apelacyjny naruszył prawo skazanego do obrony przez uznanie za oczywiście bezzasadną apelacji wniesionej przez obrońcę skazanego, opracowanej w sposób mało profesjonalny, albowiem nie ma naruszenia tego prawa gdy w złożonej przez obrońcę apelacji od wyroku sądu nie przedstawiono wszystkich zarzutów, które kasacja od wyroku sądu odwoławczego uznawała za niezbędne do prezentacji w takiej skardze, jeśli nie osiągały one charakteru uchybień domagających się oceny z urzędu (art. 440 kpk.). 


\section{Postanowienie Sądu Najwyższego z dnia 27 marca 2007 r. III KK 461/06, OSNwSK 2007 nr1, poz. 711}

Przepis art. 2 kpk., mający charakter ogólny, określa jedynie cele postępowania karnego i kilka obowiązujących w tym postępowaniu zasad (m.in. zasadę prawdy materialnej wyrażoną w art. $2 \S 2 \mathrm{kpk}$.). Skoro przepis ten nie reguluje przebiegu procesu karnego, nie może być mowy o jego naruszeniu w sposób poddający się kontroli instancyjnej. Przedmiotem naruszenia mogą być bowiem tylko normy konkretyzujące ogólne zasady procesowe, a zwłaszcza normy nakazujące lub zakazujące dokonywania określonych czynności w odpowiedniej sytuacji procesowej.

Wyrok Sądu Apelacyjnego w Lodzi z dnia 17 stycznia 2001 r. II AKa 255/00, Prokuratura i Prawo - wkładka 2002 nr 10, s. 22

Stosownie do jednolitej linii orzecznictwa Sądu Najwyższego - przekonanie sądu o wiarygodności jednych dowodów i niewiarygodności innych pozostaje pod ochroną art. 7 kpk., jeżeli:

- zostało poprzedzone ujawnieniem w toku rozprawy głównej całokształtu okoliczności sprawy, w sposób podyktowany obowiązkiem ustalenia prawdy, realizującym zasady postępowania określone w art. 410 i art. $2 \S 2$ kpk.,

- jest rezultatem rozważenia wszystkich tych okoliczności przemawiających na korzyść, jak i na niekorzyść oskarżonego, czyli z zachowaniem zasady bezstronności (art. 4 kpk.) oraz uwzględnieniem nakazu in dubio pro reo (art. $5 \S 2 \mathrm{kpk}$.).

Słowa kluczowe: postępowanie karne, wznowienie postępowania

\section{Postanowienie Sądu Apelacyjnego w Krakowie z dnia 28 kwietnia 2009 r. II AKz 144/09, KZS 2009/5/44}

W sprawie o wznowienie postępowania nowe fakty nie mogą być ustalane w oparciu o dowody uprzednio przeprowadzone w postępowaniu, bo dopuszczenie takiej możliwości oznaczałoby dokonywanie w postępowaniu o wznowienie nowej oceny dowodów i dokonywanie tylko na tej podstawie odmiennych ustaleń faktycznych, a w tym postępowaniu nie jest dopuszczalne badanie prawidłowości oceny materiału dowodowego, poprzednio dokonanej przez sądy. 


\section{Postanowienie Sądu Najwyższego z dnia 5 czerwca 2009 r. V KZ 31/09 OSNKW 2009/10/90}

Skoro strona nie ma prawa do złożenia wniosku o wznowienie postępowania z przyczyn określonych w art. $542 \S 3 \mathrm{kpk}$., to nie przysługuje jej również żądanie, w drodze środka odwoławczego, kontroli negatywnego stanowiska sądu.

\section{Wyrok Sądu Najwyższego z dnia 8 lipca 2009 r. \\ II KO 45/09, LEX nr 512964}

Jeżeli zmiana przepisu stanowiącego podstawę odpowiedzialności karnej nastąpiła w wyniku orzeczenia Trybunału Konstytucyjnego, uznającego przepis w pierwotnym brzmieniu za niezgodny z Konstytucją RP, a przepis w nowym brzmieniu jest korzystny dla prawomocnie skazanego, to istnieje określona w art. $540 \S 2$ kpk. podstawa do wznowienia postępowania. Jest oczywiste, że postępowanie ulega wznowieniu w takim zakresie, w jakim zmiana stanu prawnego ma znaczenie dla przyszłego orzeczenia.

Opracowali: Justyna Matys Piotr Niczyporuk 